2. Пискунов В.Г. Проблема построения моделей физикомеханических процессов в слоистых конструктивних системах. Механика неоднородных структур. Львов, 1987. С. 211-212.

3. Василенко А.Т., Григоренко Я.М., Панкратова Н.Д. Напряженное состояние трансверсально-изотропных неоднородных толстостенных сферических оболочек. Докл. АН СРСР. Механика твердого тела, 1976. № 1. С. 59-66.

4. Амбарцумян С.А. Теория анизотропных пластин. М.: Наука. 1987. C. 360.

5. Григолюк Э.И., Коган Ф.А. Современное состояние теории многослойных оболочек. Прикл. механика,1972. 8, № 6. С. 3-17.

6. Болотин В.В. К теории слоистых пластин. Изв. АН СРСР. Отдние техн. наук Механіка и машиностроение. 1963. № 3. С. 65-72.

7. Пискунов В.Г. Об одном варианте неклассической теориимногослойных пологих оболочек и пластин. Прикладная механика. 1979. 15, № 11. С. 76-81.

DOI https://doi.org/10.30525/978-9934-26-109-1-24

\title{
TECTONIC FORMATION OF BIOCLIMATIC HIGH-RISE BUILDINGS
}

\author{
Krivenko O. V. \\ Candidate of Technical Sciences, \\ Associate Professor at the Department of Architectural Constructions \\ Kyiv National University of Construction and Architecture
}

\author{
Bukina Yu. O. \\ Senior Lecturer at the Department \\ of Language Communication and Training \\ Kyiv National University of Construction and Architecture \\ Kyiv, Ukraine
}

The problem statement. In search for ways to develop mega cities in the balance between artificial and natural environment is becoming a general trend of our time [1, p. 8]. In modern cities, the development of high-rise buildings to improve their adaptive characteristics, the possibility 
of transformation taking into account the changing external and internal conditions, providing a reliable, comfortable and healthy environment for people living in high-rises. Research on the use during the design of natural analogues and their formation are an important area for solving various problems of bioclimatic high-rise construction. The aim of the research is to identify the relationship between natural analogues and high-altitude bioclimatic structures to determine the natural means and mechanisms for creating of bioclimatic design.

Results and discussion. In nature, the formation of various forms is associated with the principle of structural optimization, where the distribution of stress and loads harmoniously corresponds to the optimization of form and the concepts of tectonics and architectonics in design and architecture. The tasks of bioclimatic modeling of high-rise buildings are aimed at interaction with nature, which can be realized, including the use of analogues or bio prototypes of natural structures. In this way, based on the tectonic approach in the design of a high-rise building, the logic and stability of its constructive, functional and visual structure is formed, the formation of harmonious and aesthetic vertically developed objects of urban design is ensured. For natural structural systems are characterized by:

- reliability, based on the evolutionary development of selection;

- adaptability as the ability to integrate and interact with the environment to ensure vital functions;

- stability, which is determined by the means to respond quickly to influences; efficiency, which is determined by reliability with minimal energy and resource costs;

- uniqueness provided by a combination of the above characteristics.

Thus, the level of stability of the constructive decisions made on the basis of natural analogues gives the chance to increase interaction of external environment with maintenance of functionality and harmony of forms of a high-rise building. The idea of using natural design solutions as analogues in the process of architectural design of buildings has a long history [2, p. 12]. Thus, in the second half of the nineteenth century English architect J. Paxton designed a new lightweight glass ceiling design of the Crystal Palace at the Great Exhibition in London, 1851 [3] (Fig. 1b).

A natural analogue of the construction of the coating was the ribbed structure of a floating leaf of the aquatic plant of Victoria amazonica, which grows up to $2 \mathrm{~m}$ in diameter and can withstand a weight of up to $50 \mathrm{~kg}$ without sinking into the water [4]. At the bottom, the sheet is 
reinforced with thick and strong streaks connected by transverse diaphragms. So, the structural material is concentrated on the main voltage lines. In this case, the membrane of the sheet has a minimum thickness, due to this distribution of the material achieves significant strength with minimal material consumption (Fig. 1a). An analogue of the natural structure of this plant has found its place in modern structural solutions of high-rise buildings. For example, in the high-rise building of Capital Gate, in Abu Dhabi [5], a load-bearing structure with a diagonal grid was used an external exoskeleton for the perception of wind force and seismic pressure (Fig. 1c). In addition, the exoskeleton provides stability of the curvilinear shape of the building with a complex geometry with an angle of $18^{\circ} .728$ specially made diamond-shaped glass panels are attached to the edges of the grid, which are installed at different angles due to the complex geometry of the structure. In total, the tower contains more than 12,500 glasses, which significantly reduces the cost of artificial lighting. Among similar skyscrapers are 30 St Mary Ax, London, UK, as well as Hearst Tower, New York, USA.

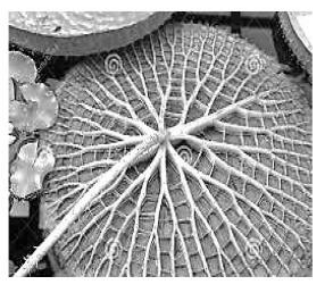

$a$

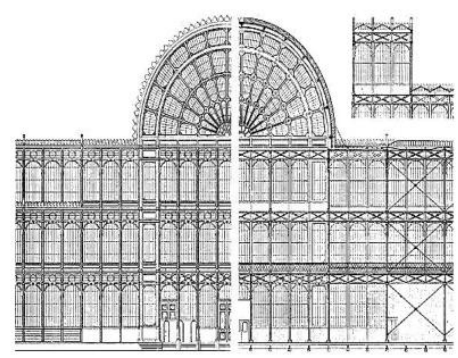

$b$

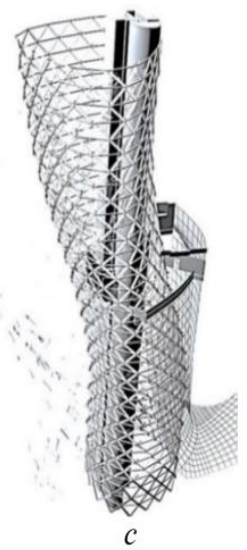

Figure 1. Application of tectonic shaping on the basis of natural analogies:

$a$ - ribbed buds of a floating leaf of the aquatic plant of Victoria amazonica [4]; $b$-Crystal Palace, the Great Exhibition in London, 1851, arch. J. Paxton [3]; c-mesh system "diagrid" in the outer shell of the high-rise building Capital Gate, Abu-Dhabi, United Arab Emirates [5] 
A natural analogue of the construction of the coating was the ribbed structure of a floating leaf of the aquatic plant of Victoria amazonica, which grows up to $2 \mathrm{~m}$ in diameter and can withstand a weight of up to $50 \mathrm{~kg}$ without sinking into the water [4]. At the bottom, the sheet is reinforced with thick and strong streaks connected by transverse diaphragms. So, the structural material is concentrated on the main voltage lines. In this case, the membrane of the sheet has a minimum thickness, due to this distribution of the material achieves significant strength with minimal material consumption (Fig. 1a). An analogue of the natural structure of this plant has found its place in modern structural solutions of high-rise buildings. For example, in the high-rise building of Capital Gate, in Abu Dhabi [5], a load-bearing structure with a diagonal grid was used an external exoskeleton for the perception of wind force and seismic pressure (Fig. 1c). In addition, the exoskeleton provides stability of the curvilinear shape of the building with a complex geometry with an angle of $18^{\circ} .728$ specially made diamond-shaped glass panels are attached to the edges of the grid, which are installed at different angles due to the complex geometry of the structure. In total, the tower contains more than 12,500 glasses, which significantly reduces the cost of artificial lighting. Among similar skyscrapers are 30 St Mary Ax, London, UK, as well as Hearst Tower, New York, USA.

Conclusions. The analysis of examples the use of bionic directions in the formation of architecture shows the prospects and the effectiveness of their application introduction and formation of a new way of life based on the development of ecological consciousness and the search for new forms of harmonious coexistence with nature. The evolution of the bionic approach in eco-design has led to a new stage, such as the need for the introduction of new strains and concepts and the formulation of the out-ofthe-box principles, adoption of the development on the basis of the analysis of folding systems and synergistic design. This is especially important for solving the problems of bioclimatic high-altitude architecture, the formation of which is associated with a significant number of parameters to achieve natural similarity not only in form and technology of formation, but also in the existence of high-rise buildings.

\section{References:}

1. O. Krivenko, V. Mileikovskyi. and T. Tkachenko, The principles of energy efficient microclimate provision in the skyscraper "Biotecton" of $1 \mathrm{~km}$ height, European J. of Formal Sciences and Engineering 1(3), 8-17 (2018) DOI: http://journals.euser.org/index.php/ejef/issue/view/273. 
2. P. Gruber, Biomimetics in Architecture. Architecture of Life and Buildings, (New York: Springer Wien 2011), 275.

3. CollectedPapers, URL: https://collectedpapers.com.ua/ru/ plants_engineers_of_the_nature/yak-buv-stvorenij-krishtalevij-palac (date retrieved 24.06.2021).

4. Victoria amazonica, Victoria Regia, URL: https://n-dank.livejournal. com/109641.html (date retrieved 24.06.2021).

5. Capital Gate Tower, Abu Dhabi, URL: https://web.archive.org/ web/20170616220958/http:/www.ctbuh.org/TallBuildings/FeaturedTallBui ldings/CapitalGateTowerAbuDhabi/tabid/3380/language/en-

GB/Default.aspx (date retrieved 24.06.2021).

DOI https://doi.org/10.30525/978-9934-26-109-1-25

\title{
ДІЛОВА КУЛЬТУРА І ГЕНОМ ДІЛОВОЇ ДОСКОНАЛОСТІ БУДІВЕЛЬНОГО ВИРОБНИЦТВА - ОСНОВА КУЛЬТУРИ ВИРОБНИЧИХ ВІДНОСИН СУСПІЛЬСТВА
}

\author{
Савенко B. I. \\ доктор технічних наук, професор, \\ доктор будівниитва АБУ \\ професор кафедри організаиії і управління будівництвом \\ Київький національний університет будівництва і архітектури
}

Полосенко О. В.

аспірант

Київський національний університет будівництва і архітектури член-корреспондент АБУ

TOB HBO «Iнтериептор»

\section{Победа С. С. \\ аспірант}

Київський національний університет будівництва і архітектури м. Київ, Україна

Питання досконалості і якості вічне питання, як і саме будівництво. Для успішної діяльності будівельної організації дуже важливо мати замовлення, а для цього треба забезпечити конкурентоспроможність 104 